Rev. Elev. Méd. Vét. Pays Trop., 1965, 19, 4 (451-456).

\title{
Note sur l'action du sulfate de sodium, du sulfate de magnésium et du chlorure de magnésium sur le virus de la peste bovine adapté aux cultures cellulaires
}

\author{
par P. ROBIN ef P. BOURDIN
}

\begin{abstract}
RÉSUMÉ
Le virus de la peste bovine atténué par passages sur cultures cellulaires, mis en solution et chauffé à $50^{\circ} \mathrm{C}$, est inactivé très rapidement en présence de chlorure de magnésium à la concentration molaire, alors qu'il est thermo-stable en présence de sulfale de magnésium ou de sulfate de sodium à la concentration molajre. La thermo-stabilité diminue avec l'abaissement de la concentration de ces deux sulfates.
\end{abstract}

Les travaux de RAPP ef WALLIS (1) sur la stabilisation thermique du virus de la rougeole par les ions sulfates et les recherches de WALLIS, MELNICK et RAPP (2) sur les effets du chlorure de magnésium et du sulfate de magnésium sur d'autres myxovirus (Influenza, Parainfluenza, Rubéole), ont fait penser que les ions sulfates devaient avoir un rôle protecteur visà-vis de l'inactivation thermique du virus de la peste bovine en solution, tandis que le chlorure de magnésium devait accélérer l'inactivation thermique de ce même virus.

\section{MATÉRIEL ET TECHNIQUE}

\section{Cultures cellulaires.}

La méthode utilisée est celle décrite par PLOWRIGHT et FERRIS (3). Les cellules proviennent de reins d'embryons de bovins de première explantation. La concentration est de $1 \mathrm{ml}$ de culot cellulaire pour $400 \mathrm{ml}$ de milieu nutritif. Ce milieu est composé d'une solution saline de HANKS enrichie de 0,5 p. 100 d'hydrolysat de lactalbumine et 0,1 p. $100^{\prime}$ d'extrait de levure, à laquelle on ajoute du sérum dans les proportions variables suivantes:

- 10 p. 100 de sérum de veau dans la suspension cellulaire de départ.

- 5 p. 100 de sérum de bœuf au premier changement de milieu qui coincide dans les expériences avec l'ensemencement du virus.

- 2 p. 100 de sérum de bœuf aux changements suivants.

Par millilitre de milieu, on ajoute 500 UI de pénicılline, 100 gamma de streptomycine, $50 \mathrm{Ul}$ de mycostatine ef 25 gamma de Kanamycine.

Pour éviter les changements de milieu trop fréquents à effectuer lorsque le virage de l'indicateur coloré indique un $\mathrm{pH}$ acide, on ajoute à partir du premier changement, 3,2 p. 100 d'une solution de bicarbonate de sodium à 25 p. 1.000 .

Souche de virus bovipestique.

Toutes les expériences sont faites avec la souche «Kabete $O$ » adaptée aux cultures cellulaires et atténuée par PLOWRIGHT et FERRIS en 1957. 
D'un stock de départ constitué en juin 1965 et conservé à l'état lyophilisé, il a été falt deux lots de virus, mélangés à parties égales avec du Mist Dessicans additionné de lactose et d'hydrolysat de lactalbumine d'après JOHNSON (4) et lyophilisé. Le titre de chacun de ces lots a été déterminé et figure au chapitre «résultats ».

\section{Sels minéraux.}

Des solutions molaires de sulfate de magnésium, de chlorure de magnésium et de sulfate de sodium sont préparées par dissolution sur agitateur d'une molécule-gramme de chacun des sels dans un litre d'eau bidistillée.

Sont également préparées, à partir des solutions molaires de sulfate de magnésium et de sulfate de sodium, des solutions diluées de ces sels contenant 0,5 mole, 0,1 mole, 0,05 mole, 0,01 mole, 0,005 mole, 0,001 mole par litre.

Les diverses solutions sont ensuite ajustées à $\mathrm{pH} 7$ par addition de soude normale, puis stérilisées par chauffage d̀ l'autoclave d̀ $120^{\circ} \mathrm{C}$.

Technique de chauffage des suspensions de virus.

Dans une première série d'expériences, l'influence des sels est appréciée par rapport à l'eau. L'abaissement du titre du virus est contrôlé à l'issue d'intervalles réguliers de temps de chauffage.

Le contenu lyophilisé de deux flacons de $1 \mathrm{ml}$ du mélange à parties égales du virus et de Mist Dessicans est dissous dans $10 \mathrm{ml}$ de la solution molaire saline dont on veut apprécier le pouvoir de conservation du virus à l'égard de la chaleur.

La même opération est réalisée avec deux autres flacons du même lot à l'aide d'eau bidistillée dont le $\mathrm{pH}$ a été ajusté à 7 .

La suspension au $1 / 10^{\mathrm{e}} \mathrm{du}$ virus ainsi obtenue est répartie, à raison de $2 \mathrm{ml}$ par tube, en cinq tubes de $12 \mathrm{~mm}$; le premier tube, placé en glace fondante, servira à déterminer le titre du virus au temps 0 . Les 4 autres tubes, placés sur un portoir, sont plongés dans un bain-marie à $50 \circ \mathrm{C}$. Chacun d'eux est successivement retiré après une durée de chauffage de $30^{\circ}, 60^{\prime}, 90^{\prime}$ ef $120^{\prime}$. Un thermomètre est placé dans un sixième tube du portoir contenant $2 \mathrm{ml}$ d'eau bidistillée, pour le contrôle de la température.

Dans une deuxième série d'expériences, l'influence des sels, esł appréciée en fonction de leur concentration, la durée de chauffage étant de 2 heures pour les diverses solutions.

\section{Dilution ef inoculation.}

A l'issue des temps de chauffage d̀ $50 \circ \mathrm{C}$. chaque tube contenant la suspension au $1 / 10 \mathrm{e} d u$ virus dans les solutions de sels ou d'eau, est retiré du bain-marie ef placé dans la glace fondante pour être soumis au titrage.

Des dilutions en séries décimales sont effectuées en solution de HANKS refroidie.

Dans la première série d'expériences, les dilutions et ensemencements sur tubes de culfures cellulaires sont effectués immédiatement dans la demi-heure suivant le retrait du tube du bain-marie.

Dans la deuxième série d'expériences et ò I'issue de la période de chauffage de deux heures. il est procédé tout d'abord à la dilution du contenu des tubes chauffés. Dans les deux séries d'expériences, les suspensions au $1 / 10^{\mathrm{e}} \mathrm{du}$ virus chauffé ainsi que leurs dilutions décimales en solution saline de HANKS sont ensemencées chacune sur 5 tubes de cultures cellulaires âgées de 3 à 5 jours, ò raison de $0,2 \mathrm{ml}$ par tube de chacune des dilutions.

Les tubes de cultures cellulaires sont ensuite placés sur un tambour roulant pendant 2 heures à $37^{\circ} \mathrm{C}$. A l'issue de ce délai, tous les tubes reçoivent $2 \mathrm{ml}$ du milieu nutritif à 5 p. 100 de sérum de bœuf.

\section{OBSERVATIONS}

Les tubes de cultures cellutaires sont observés au microscope inversé chaque jour à partir du $5 \mathrm{e}$ jour après l'ensemencement. Au $12 \mathrm{e}$ jour, les tubes sur lesquels la présence de l'effet cytopathogène n'est pas constaté sont considérés comme négatifs. Le titre final est déterminé selon la méthode de Reed et Munch.

\section{RÉSULTATS}

\section{Première expérience.}

Variations du titre du virus de la peste bovine, souche « Kabete $O$ » atténuée par passages sur cultures cellulares, en solution dans l'eau ef dans les différents sels à concentration molaire 
en fonction de la durée de chauffage à $50^{\circ} \mathrm{C}$. Les résultats sont résumés dans le graphique no 1 ,

Les titres du virus non chauffé mis en suspension dans des solutions molaires de sulfate de magnésium, de sulfate de sodium ou dans l'eau distillée sont comparables entre eux : $10^{-5,9}$ $\mathrm{DICT}_{50}$ à 10-6,3 $\mathrm{DICT}_{50}$.

Sont également comparables, les titres du virus placé en solutions molaires de sulfate de magnésium et de sulfate de sodium et chauffé $120^{\circ}$ minutes au bain-marie à $50^{\circ} \mathrm{C}$. La baisse du titre du virus placé en solution de chlorure de magnésium dans la même expérience, est très forte puisque 30 minutes de chauffage suffisent pour le détruire ef le rendre non titrable.

\section{$2^{\circ}$ Deuxième expérience.}

Variation du titre du virus de la peste bovine, souche «Kabete $O$ » atténuée par passages sur cultures cellulaires, en fonction de la concentration du sulfate de magnésium et du sulfate de sodium, après un chauffage de 2 heures au bain-marie à $50^{\circ} \mathrm{C}$. Les résultats sont résumés dans le graphique no 2 .

Les titres du virus «Kabete $O$ » chauffé pendant 2 heures à $50^{\circ} \mathrm{C}$ au bain-marie, décroissent régulièrement avec l'abaissement de la concentration molaire du sulfate de magnésium et du sulfate de sodium. Les deux courbes sont sensiblement comparables.

\section{DISCUSSION}

Il apparaît comme cela a éié observé par WALLIS, MELNICK et RAPP (2) et par RAPP, BUTEL et WALLIS (1) pour le virus de la rougeole, de l'influenza, du parainfluenza et de la rubéole que le virus de la peste bovine a un comportement identique aux autres myxovirus vis-à-vis du chlorure de magnésium, du sulfate de magnésium et du sulfate de sodium. Comme ces auteurs ont pu le démontrer pour les myxovirus étudiés au cours de leurs recherches, le virus de la peste bovine est inactivé très rapidement à $50 \circ \mathrm{C}$ en présence de chlorure de magnésium à concentration molaire, tandis que le sulfate de magnésium et le sulfate de sodium à concentration molaire lui confèrent une thermo-stabilité appréciable. Cette thermostabilité diminue avec l'abaissement de la concentration molaire.

Il conviendrait, et cela sera le but de notre prochaine expérimentation, de vérifier si le vaccin vivant contre la peste bovine, stabilisé par le sulfate de magnésium ou le sulfate de sodium, donne sur les bovins des résultats comparables au vaccin vivant non stabilisé.

\section{Institut d'Elevage et de Médecine Vétérinare des Pays Tropicaux. \\ Laboratoire National de l'Elevage \\ ef de Recherches vétérinaires du Sénégal, Dokor-Honn.}

\title{
SUMMARY
}

\author{
Nole on the action of sodium sulphate, magnesium sulphate \\ and magnesium chloride on Rinderpest virus adapted to cell culture
}

\footnotetext{
Rinderpest virus which had been attenualed by passages in cell cultures in solution and heating at $50 \% \mathrm{C}$, was very quickly inactivated.

In the presence of magnesium chioride at molar concentration, but it is thermostable in the presence of magnesium sulphate and sodium sulphate at molar concentration. The thermostability was decreasing in relation to the concentration of both sulphates.
} 


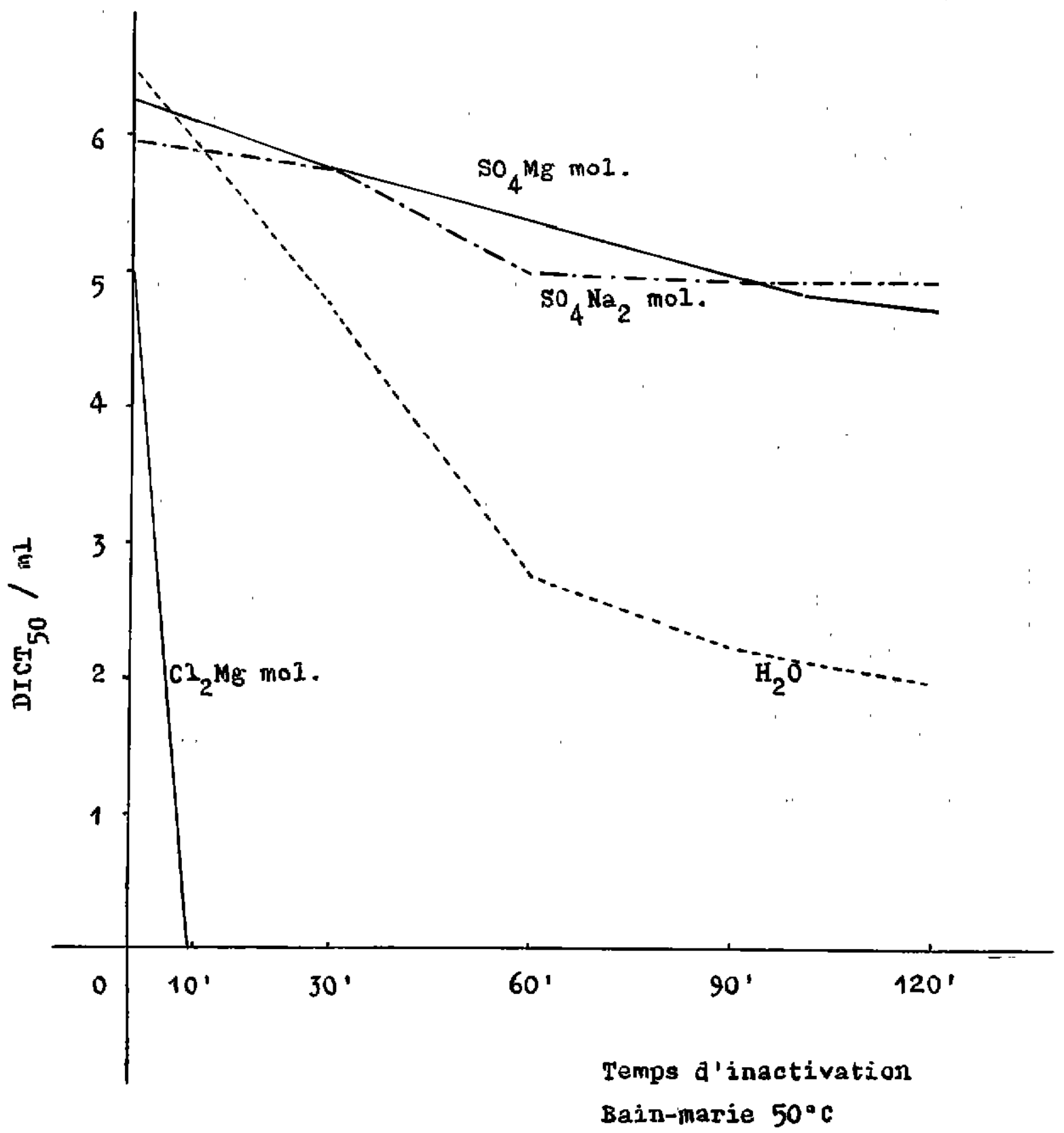

N'1- Courbe d'inactivation du virus "Kabete O" en solution de sels et dans I'eau en fonction de la durée de chauffage à $50^{\circ} \mathrm{C}$ 


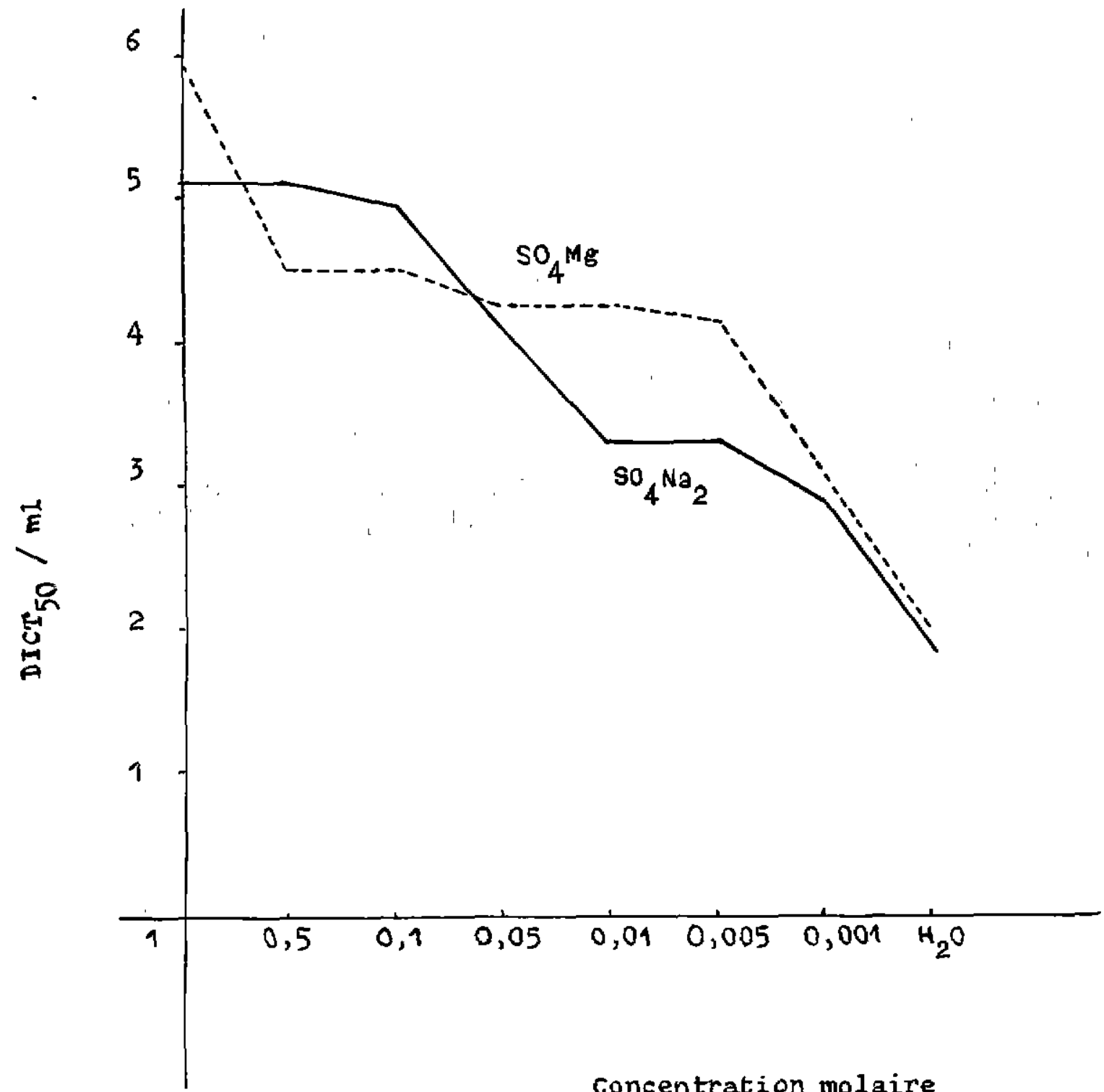

concentration molaire

N.2- Stabilité du virus "Kabete 0 " en fonction de la concentration du sulfate de magnésium et du sulfate de sodivim. 


\section{RESUMEN}

Nota sobre la acción del sulfato de sodio, del sulfato de magnesio y del cloruro de magnesio sobre el virus de la peste bovina adaptado con los cultivos celulares

El virus de la peste bovina atenuado por pasajes sobre cultivos celulares, en saluciôn y calenfado a $50^{\circ} \mathrm{C}$, se inactiva muy rapidamente con la presencia del cloruro de magnesio de concentración molar, mientras que es termoestable con la presencia del sulfato de magnesio o del sulfato de sodio de concentración molar. La termoestabilidad va disminuyendo con el descenso de la concentración de estos dos sulfatos.

\section{BIBLIOGRAPHIE}

1. RAPP (F.), BUTEL (J. S.) ef WALLIS. Protection of measles virus by sulfate ions against thermal inactivation. J. Bacteriol. 1965, 90. 132-135.

2. WALLIS (C.), MELNICK (J. L.) and RAPP $\left(E_{1}\right)$. - Different effects of $\mathrm{MgCl}_{2}$ and $\mathrm{MgSO}_{4}$ on the thermostability of viruses. Virology, $1965,26,694-699$.
3. PLOWRIGHT et FERRIS. - Studies with Rinderpest virus in tissue culture. A technic for defection and titration of virulent virus in cattle tissue. Res. Vet. Sci., 1962, 3, 94.

4. JOHNSON (R, H.). - Rinderpest in tissue culture. I. Methods for virus production. Brit. Vet. J. 1962, 118, 107. 